\title{
Impact of Chemical Oxidation on Brazilian Soils
}

\author{
Leandro A. da Silva, ${ }^{a}$ Silvio C. G. Teixeira, ${ }^{a}$ Daniel V. Pérez ${ }^{b}$ and Mônica R. da C. Marques*,a \\ ${ }^{a}$ Instituto de Química, Universidade do Estado do Rio de Janeiro, \\ Rua São Francisco Xavier, 524, Maracanã, 20550-900 Rio de Janeiro-RJ, Brazil \\ ${ }^{b}$ Empresa Brasileira de Pesquisa Agropecuária, Embrapa, Centro Nacional de Pesquisa de Solo, \\ Jardim Botânico, 1029, 22460-000 Rio de Janeiro-RJ, Brazil
}

\begin{abstract}
Neste trabalho, foram avaliados os impactos na composição mineralógica e nas propriedades físico-químicas de duas categorias representativas de solos brasileiros - um vertissolo (V) e um argissolo $(\mathrm{P})$ - após tratamento com reagente de Fenton. Os argilominerais presentes no V, rico em argilas expansivas, sofreram degradação após o tratamento pelo reagente de Fenton. No solo $\mathrm{P}$, rico em caulinita, não foi observada nenhuma alteração significativa na mineralogia de sua fração argila após este tratamento. A capacidade de troca catiônica (CTC) de V foi drasticamente diminuída, o que em longo prazo poderá causar a infertilidade do solo por causa da redução da sua capacidade de retenção de água e nutrientes.
\end{abstract}

In this work, the impacts on the mineralogical composition and on the physico-chemical properties of two representative categories of Brazilian soils - a vertisol (V) and a kandiudult (P) - after treatment with Fenton reagent were studied. The clay minerals presented in the $\mathrm{V}$ (rich in 2:1 expansive clay) have been degraded with this reagent application. In the other, $\mathrm{P}$, rich in kaolinite, there was no significant change in its clay mineralogy after this treatment. Furthermore, the cation exchange capacity (CEC) of V was dramatically diminished and consequently can cause the soil infertility by the reduction of water and nutrients retention.

Keywords: Fenton, clay minerals, Brazilian soils

\section{Introduction}

Soil is the layer of the earth's surface in direct contact with the atmosphere. ${ }^{1}$ It consists of solid, liquid (soil solution) and gaseous portions, not entirely separated and in dynamic equilibrium. It has a mix of weathered minerals and organic matter. As a key component of terrestrial ecosystems, soil is the main substrate for sustaining life on the planet, because it is where plants grow and fix the sun's energy in the form of biomass. It also provides water and nutrients essential for plant development. ${ }^{2,3}$

The process of soil formation depends on weathering, which is the action of the environment on mineral and organic matter. Environmental factors that influence this process are rainfall, wind, water bodies and temperature variation, among other factors. ${ }^{1}$

The clay minerals and the organic matter were responsible for providing water, nutrients and pollutant

*e-mail: monica@pesquisador.cnpq.br sorptions. ${ }^{4-7}$ The sorption capacity of a soil can partly be evaluated by its particle size and its physicochemical properties, as example: $\mathrm{pH}$, cation exchange capacity (CEC) and organic matter content. ${ }^{8-10}$

Soils in tropical regions are more developed than soils in cold climates because of the high temperature variations and high rainfall which facilitates the hydrolysis of silicates. The soil profiles are deeper and show changes and sometimes even neoformations of clay minerals, which depend crucially on the position of the bedrock. ${ }^{11,12}$

Regarding the mineral composition, soils from tropical areas have kaolinite as the dominant clay mineral associated with illite and montmorillonite in some cases. ${ }^{13,14}$

Soils contaminated by non-biodegradable organic compounds are usually treated by advanced oxidative process where strong chemical oxidants are added to destroy these substances. ${ }^{15}$

Fenton's reagent is a chemical oxidizing agent commonly used in the remediation of contaminated soils. ${ }^{15-20}$ This process is based on the reaction between 
$\mathrm{Fe}^{2+}$ and $\mathrm{H}_{2} \mathrm{O}_{2}$ to produce highly reactive intermediate hydroxyl radicals $\left({ }^{\circ} \mathrm{OH}\right)$ which are able to oxidize organic contaminants. The Fenton-like reaction is based on the reaction between $\mathrm{H}_{2} \mathrm{O}_{2}$ and $\mathrm{Fe}$ oxides such as magnetite or hematite. These heterogeneous systems offer several advantages such as no sludge formation and the operation can happen at around-neutral $\mathrm{pH} .{ }^{16}$

Side-effects of oxidation processes on soil quality have been investigated only through the analysis of toxic metabolites. The effect of oxidant on soil organic matter is also highly reported. ${ }^{21}$ However, there is not enough information on the oxidation effect on mineralogical and some physicochemical soil properties. This is relevant considering soil fertility.

Sirguey et al. ${ }^{21}$ applied Fenton's reagent to a cambisol collected in France and found a significant decrease in organic carbon in soils and a reduction of soil CEC directly linked to the mineralization of organic matter. These authors also observed that, after the application of the technique, seedling growth was slower in the treated soil samples than in the untreated ones.

Hence, the aim of this study was to evaluate the impact of applying Fenton reactions on the mineralogy of two different Brazilian soils (kandiudult and vertisol). Kandiudult (P) soils, an acid soil rich in kaolinite, occur in all regions of Brazil and covers approximately $20 \%$ of the country's landmass. On the other hand, vertisol (V) soils, which the content is predominantly of 2:1 expansive clays, cover only $2 \%$ of the country. However, it is the most common soil type in dry northeastern Brazil. ${ }^{13}$ This soil has high chemical fertility, but it presents problems of physical nature, such as the formation of dry crusts and rigidity when dry. ${ }^{22}$

\section{Experimental}

\section{Samples of Brazilian soils}

A surface horizon $(0-15 \mathrm{~cm})$ of two types of Brazilian soils: vertisol (V) from Juazeiro (Bahia State) and kandiudult (P) from Seropedica (Rio de Janeiro State). The samples were dried in air for 2 days and sieved at $2 \mathrm{~mm}$.

\section{Impact assessment of soil chemical oxidation technique}

An amount of $50 \mathrm{~g}$ of each soil ( $\mathrm{P}$ and $\mathrm{V}$ ) were placed into beakers with $0.2 \mathrm{~mol}$ of $\mathrm{H}_{2} \mathrm{O}_{2}$ and $0.005 \mathrm{~mol}$ of $\mathrm{FeSO}_{4}$ and stirred at $250 \mathrm{rpm}$ using a mechanical stirrer at room temperature for $12 \mathrm{~h}$. For avoiding the very energetic oxidation, the reaction was carried out in slightly acidic $\mathrm{pH}$ (6.0). After this period, the samples were washed thoroughly with distilled water until the complete removal of the oxidizing agent and then were dried at room temperature. The presence of residual peroxide was monitored through tests with metavanadate. ${ }^{23}$ The clays after reactions are designated as "PR" or "VR", respectively. All experiments were performed in triplicate and values shown are the average.

Chemical characterization of soils before and after treatment with Fenton's reagent

The soil analysis followed the methodology from Embrapa $^{23}$ as summarized below: organic carbon (OC) was measured by oxidizing the organic matter with potassium dichromate in acid medium and titrating this with ferrous ammonium sulfate. The cation exchange capacity (CEC) was calculated from the sum of $\mathrm{Ca}+\mathrm{Mg}+\mathrm{Na}+\mathrm{K}+\mathrm{Al}+\mathrm{H}$ (Ca and $\mathrm{Mg}$ obtained from $\mathrm{KCl} 1 \mathrm{~mol} \mathrm{~L}^{-1}$ extraction; $\mathrm{Na}$ and $\mathrm{K}$ obtained from Mehlich 1 extraction $\left(\mathrm{HCl} 0.05+\mathrm{H}_{2} \mathrm{SO}_{4}\right.$ $0.0125 \mathrm{~mol} \mathrm{~L}^{-1}$ ); finally $\mathrm{Al}$ and $\mathrm{H}$ obtained from $0.5 \mathrm{~mol} \mathrm{~L}^{-1}$ calcium acetate extraction). The chemical analysis were determined by fusing the sample in an $\mathrm{Na}_{2} \mathrm{CO}_{3}+\mathrm{K}_{2} \mathrm{CO}_{3}$ mixture, dissolving the melted beads in distilled water and analyzing the solutions in a Spectra OPTIMA 3000 ICP/OES.

The mineralogy characterizations of soils were done with clay-size fractions from the soils before and after treatment with Fenton's reagent. The fraction $<2 \mu \mathrm{m}$ from soils, i.e., kandiudult (called AP before reaction and APR after reaction) and vertisol (called AV before reaction or AVR after reaction) were obtained by sedimentation. The clay-size fraction of each soil was extracted shaken in $0.5 \mathrm{~mol} \mathrm{~L}^{-1} \mathrm{NaOH}$ for $24 \mathrm{~h}$. The suspension was sifted through the 270 mesh sieve and exhaustive washing with water. Then, it was transferred into a $1000 \mathrm{~mL}$ graduated cylinder filled with water for $24 \mathrm{~h}$. The first $200 \mathrm{~mL}$ were collected and the clay was dried in air at $45^{\circ} \mathrm{C}$.

The clay-size fractions ( $3 \mathrm{~g}$ ) of the soil $\mathrm{P}$ and $\mathrm{V}$ before and after the Fenton reaction were macerated, transferred into centrifuge tubes and submitted to ultrasound for $3 \mathrm{~min}$ with $50 \mathrm{~mL}$ of distilled water for the clays dispersion. After this period, the samples were submitted to centrifugation at $18,000 \mathrm{rpm}$, and the clays were divided into three fractions: The first fraction was analyzed by X-ray powder diffraction (XRD) with a microscope slide oriented in a Rigaku model Miniflex II apparatus, scanning from 2 to 45 . The X-ray source used was a copper tube, emitting $\mathrm{K}_{\alpha}$ radiation. The second fraction was transferred into $100 \mathrm{~mL}$ test tube and washed three times with aqueous $0.1 \mathrm{~mol} \mathrm{~L}^{-1} \mathrm{KC} 1$. After the removal of the supernatant, the clays saturated with $\mathrm{K}$ were centrifuged at 18,000 rpm and then washed with 
Table 1. Chemical analysis of soils before and after remediation with the Fenton reaction

\begin{tabular}{|c|c|c|c|c|c|c|c|c|c|c|c|c|}
\hline \multirow{2}{*}{ Soil } & $\mathrm{SiO}_{2}$ & $\mathrm{Al}_{2} \mathrm{O}_{3}$ & $\mathrm{Fe}_{2} \mathrm{O}_{3}$ & $\mathrm{TiO}_{2}$ & $\mathrm{Ca}^{2+}$ & $\mathrm{Mg}^{2+}$ & $\mathrm{K}^{+}$ & $\mathrm{Na}^{+}$ & $\mathrm{Al}^{3+}$ & $\mathrm{H}^{+}$ & CEC & \multirow{2}{*}{$\begin{array}{c}\mathrm{OC} / \\
\left(\mathrm{g} \mathrm{kg}^{-1}\right)\end{array}$} \\
\hline & \multicolumn{4}{|c|}{ (wt. \% as element oxides) } & \multicolumn{7}{|c|}{$\left(\mathrm{cmol}_{\mathrm{c}} \mathrm{kg}^{-1}\right)$} & \\
\hline $\mathrm{P}$ & 101 & 77 & 20 & 3.5 & 1.60 & 1.10 & 0.11 & 0.04 & 0.40 & 2.40 & 5.45 & 7.8 \\
\hline PR & & & & & 0.80 & 0.80 & 0.04 & 0.07 & 0.20 & 1.70 & 3.81 & 1.0 \\
\hline $\mathrm{V}$ & 163 & 128 & 45 & 5.6 & 28.30 & 1.90 & 0.26 & 0.25 & n.d. & n.d & 30.70 & 5.6 \\
\hline VR & & & & & 12.40 & 0.90 & 0.11 & 0.09 & n.d. & n.d & 13.50 & 0.9 \\
\hline
\end{tabular}

P: kandiudult soil; PR: kandiudult soil treated with pseudo-Fenton; V: vertisol; VR: vertisol soil treated with pseudo-Fenton; n.a.: not analysed; n.d.: not determined; OC: organic carbon; $\mathrm{cmol}_{\mathrm{c}} \mathrm{kg}^{-1}$ : centimol positive charge per $\mathrm{kg}$ of soil.

deionized water APK and AVK. The clays were spread over microscope slide oriented, dried in air and analyzed by XRD. Then, these slides were heated at $110^{\circ} \mathrm{C}$ for $2 \mathrm{~h}$, and re-analyzed by XRD. Finally, these slides were heated at $350{ }^{\circ} \mathrm{C}$ or $550{ }^{\circ} \mathrm{C}$ for $2 \mathrm{~h}$ and again analyzed by XRD. The third fraction was transferred to another centrifuge tube and a $100 \mathrm{~mL} \mathrm{MgCl} 20.1 \mathrm{~mol} \mathrm{~L}^{-1}$ was added. After $12 \mathrm{~h}$ of contact, the clay saturated with $\mathrm{Mg}$ samples were centrifuged at 18,000 rpm, and the clays were washed with deionized water. These samples were spread over microscope slide oriented, kept in a desiccator with a container containing ethylene glycol for $15 \mathrm{~h}$ and also submitted to XRD as described above..$^{23}$

\section{Results and Discussion}

Table 1 shows the chemical characterization, as element oxides, of the soils studied (kandiudult - $\mathrm{P}$ and vertisol - V) before the treatment with Fenton's reagent. All the Fenton reaction conditions used were obtained from a previous experiment described by Pereira et al. ${ }^{16}$ for Brazilian soil decontamination: $0.2 \mathrm{~mol}$ of $\mathrm{H}_{2} \mathrm{O}_{2}$ and $0.005 \mathrm{~mol}$ of $\mathrm{FeSO}_{4}$. The proportion of organic carbon in these soils is similar and decreased after treatment due to oxidation of organic matter by hydrogen peroxide.

The cation exchange capacity (CEC) of soil $\mathrm{V}$ is much higher than soil P. Besides, in $\mathrm{V}, \mathrm{Ca}^{2+}$ content is the predominant interlamelar cation which causes the interlayer distance stability when it is hydrated. In both soils, the cations interchange $\left(\mathrm{Ca}^{2+}, \mathrm{Mg}^{2+}, \mathrm{K}^{+}\right.$and $\left.\mathrm{Na}^{+}\right)$and consequently their CEC have decreased after treatment with Fenton's reactions.

Figure 1a shows the kandiudult clay-size (AP) patterns studied by XRD. The patterns show peaks at $2 \theta=26.64^{\circ}$ (quartz) as well as kaolinite $\left(2 \theta=12.25^{\circ}\right)$, traces of muscovite $\left(2 \theta=17.65^{\circ}\right)$ and also a small reflection at $2 \theta=8.45^{\circ}$. The occurrence of reflections at $2 \theta<9^{\circ}$ in XRD pattern of the natural sample indicates the presence of 2:1 clay minerals, whose identification requires specific treatments, which include Mg saturation and solvation with ethylene glycol, and K saturation, followed by heating at different temperatures. The montmorilonites expand their interlayer space after $\mathrm{Mg}$ saturation and solvation with ethyleneglycol. Vermiculites and chlorites only alter their basal spacings at temperatures above $550{ }^{\circ} \mathrm{C}$ and illite do not change after these treatments. ${ }^{24}$

Hence, slides containing AP material were saturated with $\mathrm{K}^{+}(\mathrm{APK})$ and then were heated at 110,350 or $550^{\circ} \mathrm{C}$. The maintenance of $2 \theta=8.45^{\circ}$ reflection suggests that there is not a significantly shift in d-spacing (Figure 1a). The same results were observed in clays $\mathrm{Mg}$ and ethyleneglycol saturated (APMg), which confirms the illite presence.

Results by XRD from APR, clay fractions extracted after oxidation, indicate there was no qualitative change in the mineral assemblage observed (Figure 1b). It should be emphasized that the intensity of XRD peaks of oriented
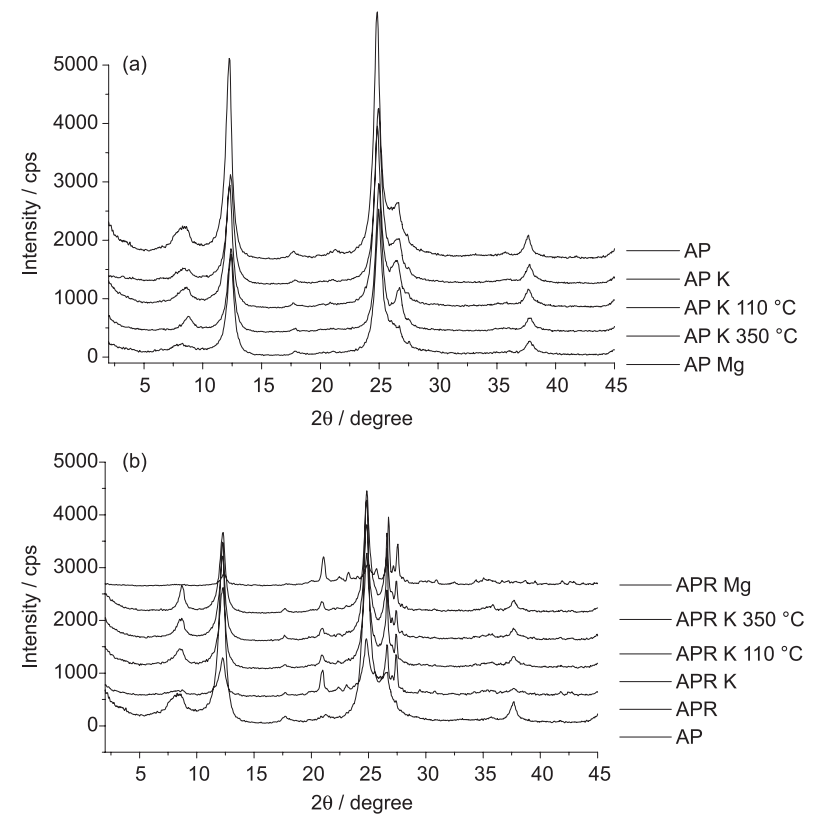

Figure 1. Powder XRD patterns of the $<2 \mu \mathrm{m}$ fractions from Kandiudult soils: (a) AP: before reaction with Fenton's reagent; APK: AP treated with $\mathrm{K}$; AP K $110^{\circ} \mathrm{C}$ : AP treated with $\mathrm{K}$ and heated at $110^{\circ} \mathrm{C}$; APK $350{ }^{\circ} \mathrm{C}$ : $\mathrm{AP}$ treated with $\mathrm{K}$ and heated at $350^{\circ} \mathrm{C}$; (b) APR: AP after reaction with Fenton's reagent; APR K: APR treated with K; APR K $110^{\circ} \mathrm{C}$ : APR treated with $\mathrm{K}$ and heated at $110^{\circ} \mathrm{C}$; APK $350^{\circ} \mathrm{C}$ : APR treated with $\mathrm{K}$ and heated at $350^{\circ} \mathrm{C}$. 
slides changes due to many factors and thus cannot be used for quantitative discrimination..$^{25}$

The $2 \theta=6^{\circ}$ reflection of the row oriented slides XRD from AV clay (Figure 2a) also suggests a presence of the expansive or 2:1 swelling clays. So, part of the AV clay sample was saturated with $\mathrm{K}^{+}(\mathrm{AVK})$ followed by various thermal treatments $\left(110,350\right.$ and $\left.550^{\circ} \mathrm{C}\right)$. Another part was saturated with $\mathrm{Mg}(\mathrm{AVMg})$. In this case, the shift of the diffraction band to lower values of $2 \theta=6.15^{\circ}$ (Figure 2) suggests that soil $\mathrm{V}$ is composed predominantly of montmorillonite.
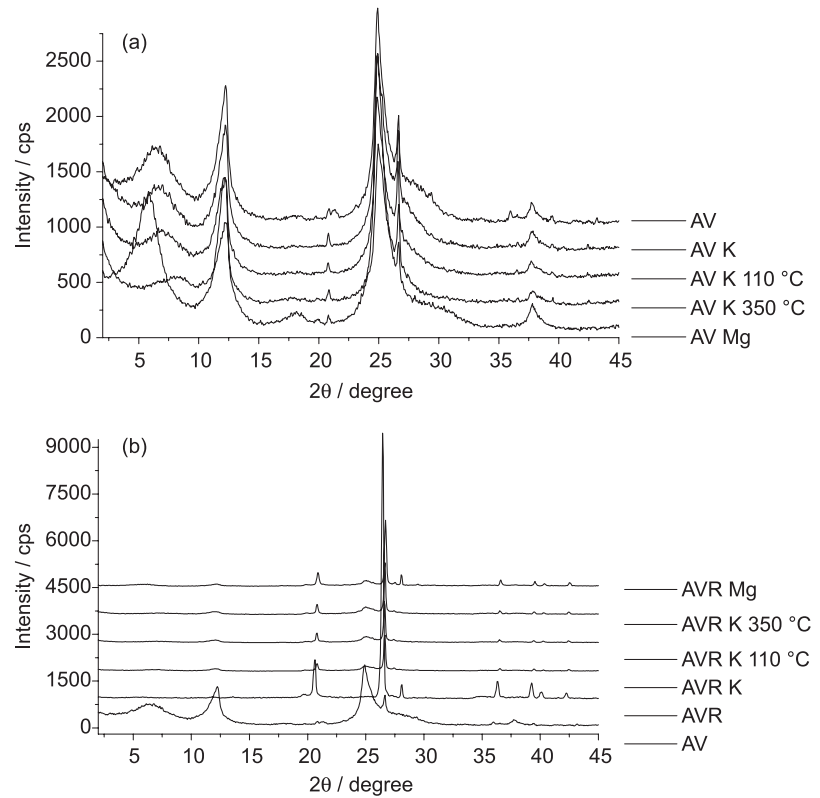

Figure 2. X-ray diffractograms of clays extracted from Vertisol soils: (a) AV: clay before reaction with Fenton's reagent; $\mathrm{AV} \mathrm{K}$ : AV treated with K; $\mathrm{AV} \mathrm{K} 110{ }^{\circ} \mathrm{C}$ : $\mathrm{AV}$ treated with $\mathrm{K}$ and heated at $110^{\circ} \mathrm{C}$; $\mathrm{AV} \mathrm{K} 350^{\circ} \mathrm{C}$ : $\mathrm{AV}$ treated with $\mathrm{K}$ and heated at $350^{\circ} \mathrm{C}$; (b) AVR: $\mathrm{AV}$ after reaction with Fenton's reagent; AVR K: AVR treated with K; AVR K $110{ }^{\circ} \mathrm{C}$ : AVR treated with $\mathrm{K}$ and heated at $110^{\circ} \mathrm{C}$; AVR $\mathrm{K} 350^{\circ} \mathrm{C}$ : AVR treated with $\mathrm{K}$ and heated at $350^{\circ} \mathrm{C}$.

Kaolinite (P soils) and montmorillonite (V soils) have very different characteristics. The 2:1 montmorillonite crystallites are composed of two tetrahedral silicon oxide sheets and one octahedral aluminum-hydroxide sheet intercalated. It presents a high permanent surface charge, large surface area, and high cation exchange capacity (CEC). Kaolinites are 1:1 aluminosilicates layer with a low surface area and a low CEC. ${ }^{25}$

The XRD of APR showed there was no qualitative change after the Fenton reactions in P soils (Figure 1). Thus, the CEC decrease was not due to mineralogy changes, but only to the organic matter decrease because of its oxidation in this soil (Table 1).

Finally, the XRD of AVR presented huge changes in the soil mineralogy. The montmorilonite reflections disappeared, which indicated its destruction. This fact added to the low organic matter contents observed in the AVR can explain the high absolute decrease in CEC (Table 1) compared to AV. The drastic reduction of the CEC causes the soil infertility by the reduction of water and nutrients retention in clay soils. ${ }^{21}$ This negative impact did not occur in soils rich in kaolinite $(\mathrm{P})$ and should not occur in soils in cold climates, rich in sand.

\section{Conclusions}

The impact application of Fenton's reagent on the properties of two Brazilian soils was studied. The treatment of Vertisoil (V) was modified important properties of the soil; that is, the organic matter content and swelling clays, due to degradation of montmorillonite present in this soil. This modification dramatically diminishes the CEC and consequently may cause the soil infertility by the reduction of water and nutrients retention in clay soils. Thus, our data suggest that it is necessary to evaluate the mineralogy of the soil prior to remediation so that this does not become inappropriate for a possible reforestation.

\section{Acknowledgments}

We thank the Rio de Janeiro State Research Foundation (FAPERJ) and the National Foundations (CAPES and $\mathrm{CNPq}$ ) for financial support. This work is part of the National Institute of oil and gas (INOG-UERJ).

\section{References}

1. Mello, J. W. V.; Perez, D. V. In Química e Mineralogia do Solo; Melo, V. F.; Alleoni, L. R. F., eds.; Sociedade Brasileira de Ciências do Solo: Viçosa, MG, Brasil, 2009, ch. 2.

2. Baird, C.; Química Ambiental, $3^{\text {rd }}$ ed.; Livros Técnicos e Científicos: São Paulo, Brasil, 2002.

3. Sposito, G.; The Surface Chemistry in Natural Particles, $2^{\text {nd }}$ ed., Oxford: Nova York, 2004.

4. Lepsch, I. F.; Formação e Conservação dos Solos, $1^{\text {th }}$ ed., Oficina dos Textos: São Paulo, Brasil, 2002.

5. Sparks, D. L.; Environmental Soil Chemistry, $2^{\text {nd }}$ ed., Academic Press: San Diego, 2003.

6. Santos, H. G.; Sistema Brasileiro de Classificação de Solos, $2^{\text {nd }}$ ed., Embrapa: Rio de Janeiro, Brasil, 2006.

7. Gomes, C. F.; Argilas, o Que São e Para Que Servem, $2^{\text {nd }}$ ed.; Fundação Calouste Gulbenkian: Lisboa, Portugal, 1988.

8. Teixeira, S. C. G.; Marques, M. R. C.; Canela, M. C.; Ziolli, R. L.; Pérez, D. V.; Rev. Chim. 2009, 60, 583.

9. Kimble, K. D.; Chin, Y.; J. Contam. Hydrol. 1994, 17, 129.

10. Leboeuf, E.; Weber, W. J.; Environ. Sci. Technol. 2000, 34, 3632. 
11. Weber, O. L. S.; Martins, E. L.; Dores, E. F. G. C.; Curado, L. D. A.; Quim. Nova 2009, 32, 2259.

12. Chiou, C. T.; Lee, J. F.; Boyd, S. A.; Environ. Sci. Technol. 1990, 24, 1164.

13. Resende, M.; Curi, N.; Rezende, S. B.; Correa, G. F.; Pedologia, Base para Distinção de Ambientes, $5^{\text {th }}$ ed.; Editora Ufla: Lavras, MG, Brasil, 2007.

14. Lu, M.; Zhang, Z.; Qiao, W.; Wei, X.; Guan, Y.; Ma, Q.; Guan, Y.; Bioresour. Technol. 2010, 101, 2106.

15. Sun, H. W.; Yan, Q. S.; J. Hazard. Mater. 2007, 144, 164.

16. Pereira, C. A.; Marques, M. R. C.; Pérez, D. V.; Quim. Nova 2009, 32, 2200.

17. Villa, R. D. ; Trovó, A. G.; Nogueira, R. F. P.; J. Braz. Chem. Soc. 2010, 21, 1088.

18. Sirguey, C.; Silva, P. T. D. E.; Schwartz, C.; Simonnot, M. O. Chemosphere 2008, 72, 282.

19. Siqueira, J. O.; Soares, C. R. F. S.; Santos, J. G. D.; Schneider, J.; Carneiro, M. A. C.; Tópicos em Ciências do Solo, $1^{\text {th }}$ ed.; Sociedade Brasileira de Ciências do Solo: Viçosa, MG, Brasil, 2007.
20. Leifeld, J.; Kögel-Knabner, I.; Soil Biol. Biochem. 2001, 33, 2155.

21. Sirguey, C.; Silva, P. T. D. E.; Schwartz, C.; Simonnot, M. O.; Chemosphere 2008, 72, 282.

22. Empresa Brasileira de Pesquisa Agropecuária (Embrapa); Manual de Métodos de Análise de Solo, $2^{\text {nd }}$ ed., Embrapa-CNPS: Rio de Janeiro, Brasil, 1999.

23. Teixeira, S. C. G.; Mathias, L.; Canela, M. C.; Quim. Nova, 2003, 26, 931.

24. Calderano, S. B.; Duarte, M. N.; Gregoris, G.; Comun. Tec.Embrapa, 2009, 53, 1.

25. Brindley, G. W. In Crystal Structures of Clay Minerals and their X-ray Identification, Brindley, G. W.; Grown, G., eds.; Mineralogical Society: Londres, 1980, ch. 2.

Submitted: September 1, 2011 Published online: December 15, 2011 